\title{
A Conceptual Proposal for Mobile Learning Interactive Courseware for Basic French-Malay
}

\author{
Nur Aina Sakinah Mohamad Haris ${ }^{1}$, Shamsul Arrieya Ariffin ${ }^{2 *}$ \\ ${ }^{1}$ Computing Department, FSKIK, Sultan Idris Education University; d081661@siswa.upsi.edu.my \\ ${ }^{2}$ Computing Department, FSKIK, Sultan Idris Education University; shamsul@fskik.upsi.edu.my
}

* Corresponding author

To cite this article (APA): Mohamad Haris, N. A. S. \& Ariffin, S. A. (2021). A conceptual proposal for mobile learning interactive courseware for basic French-Malay. Journal of ICT in Education, 8(2), 71-78.

https://doi.org/10.37134/jictie.vol8.2.7.2021

To link to this article: https://doi.org/10.37134/jictie.vol8.2.7.2021

\begin{abstract}
In this study, an interactive mobile learning web-based system will be developed, 'Basic French-Malay Words,' especially for the first-timer students taking French subjects in schools or universities. The goal of this system's development is to learn the challenges that Malay language students have understanding French as a foreign language utilising existing traditional approach. To address this issue, the initial goal of this research is to establish the system requirements that will make a good learning platform. The next step is to create a mobile learning web-based system that will assist students in overcoming the challenges that arise. The final goal is to assess students' and educators' satisfaction with the application's usefulness. As a result, the purpose of this research is to design and construct a mobile web-based system for students to learn French in Malay. The methodology used for identifying the requirements is from the literature review content analysis and interviews. The Waterfall Model is used in software development, and heuristic evaluation is used in software evaluation. Finally, the anticipated outcome will be the requirements, software prototype, and level of user satisfaction with this mobile learning web-based system. As a result, the conceptual idea for this research is presented in this paper.
\end{abstract}

Keywords: content analysis, heuristic evaluation, learning web-based system, Waterfall model.

\section{INTRODUCTION}

The ease of use of technology is now obvious, as it aids in the facilitation of daily activities, particularly in the sphere of education. Technology integration also gives many benefits to the learning experience in education, especially language learning at school. Andreas and Peter (2018) stated that over the years, foreign language learning has benefited from the use of computer technology. Nonetheless, efforts to integrate technology have confronted educators with a variety of 
obstacles due to rapid technical improvements and occasional shifts in language teaching approaches. Nonetheless, the study shows that technology has been used for language acquisition all around the world in recent years. Karabulut, LeVelle, Li, and Suvorov (2012), on the other hand, pointed stated that the advantages of technology have boosted the use of technology in foreign language teaching Today, there is a rising use of technology in studying French as a foreign language, which corresponds to its popularity and benefits. As a result, there is a strong indication that technologies are having a significant impact on how we learn since it is more convenient for us.

As foreign language growth has increased worldwide in the past few decades, Malaysia is also on the same path. Proof of this has been said by the former Education Minister, Dr Maszlee Malik; the ministry collaborated with various parties both at local and international levels to strengthen efforts towards getting students to command a foreign language (Azneal, 2018). The actions that have begun in the Malaysian education system that many schools and universities have offered foreign language learning such as French, Spain, Japan, and Arabic for students to learn for some time now. This whole situation shows that language learning has a massive impact in Malaysia due to its globalization.

As far as we can tell, there are several language study or translation applications available on the Internet. The well-known Duolingo language learning applications, for example, are popular due to their interactivity and ease of use. Parkinson and Dinsmore (2019) concluded that Duolingo's approach to creating declarative and procedural knowledge is excellent. Technology learning techniques in school have expanded due to the numerous benefits that an individual may receive from it - the research done by Gabarre, Gabarre, Ding, Mohd Shah, and Abdul Karim. (2021) concluded that the use of technology, such as mobile learning, enables students and instructors to execute a variety of tasks more quickly (Ariffin \& Afif, 2020). As a result, the technology technique in education, particularly for language learning, allows for the enjoyment of facilities.

As a result, rather than the traditional classroom method, this study is about a mobile learning webbased system that allows students and lecturers to learn French in an interactive manner. It is because of the ability to discover content utilizing a mobile device that can be used whenever and wherever to assist students in enhancing their French language command using Malay as their mother tongue. As a result, learning through mobile learning web-based software is engaging and inspiring enough to be used in daily schooling.

\section{BACKGROUND}

Due to the widespread use of communication in French, the lingua franca of various countries, especially in West and Central Africa. According to Wood (2019), it is the official language of countries on five continents. It is also the world's second most studied language, after English: 120 
million students are currently learning French. In addition, it is a language of international diplomacy, a global business language, and a top internet language, which points to the growing importance of French (Ward, 2017). Malaysia is not left behind in studying the French language because of its economic ties with France because of diplomatic foundations created between the two countries. Another example is the school built in the capital city of Kuala Lumpur named Lycée Français de Kuala Lumpur, which provides an excellent environment for academic excellence based on the teaching of various languages.

The rate of having to acquire a foreign language has sparked a lot of interest from a variety of parties. It would not be an exaggeration to argue that these policies will propel Malaysians into prominent positions in the global economy, politics, and international relations in the future (Bajunid, 2018). Furthermore, it might be advantageous for students or graduates on the job market to acquire foreign languages such as French. As a result, the ministry places a premium on language abilities, particularly foreign languages, to enhance the national education system. From an article written by Azneal (2018), the former Minister of Education, Dr Maszlee Malik towards this, the ministry had highlighted eleven major steps to overhaul the country's education system, one of which was to improve students' language skills, including Malay, English, and Arab, and to encourage them to acquire other foreign languages as well.

Most of the debates over third language instruction revolve around the topic of competency. Because mother tongue education is always emphasized in Malaysian schools, developing software translated into Malay can aid in the study of a third language. According to the research done by Yusof et al. (2011), the present language learning websites are largely unsuitable for the syllabus, so we intended to build a platform for the syllabus as a template in Malay. Most language learning programs that have been developed use English as the primary language to be translated. Considering that there is still a scarcity of software for language instruction that is predominantly translated in Malay. As a result, the instilling of Malay language will be heavily used in this learning language software to benefit local students.

Compared to the traditional method of developing software, the use of technology in language acquisition has several advantages. A mobile learning web-based system allows students to learn anywhere and at any time, provides a variety of content, and encourages students to learn more effectively by providing an interactive environment. Furthermore, employing technology as a platform for language acquisition fosters intrinsic motivation to complete activities (Gabarre, Gabarre, Din, Shah, \& Karim, 2015). To summarize, many aspects of software technology work well for language instruction because many sources are available online, making it sustainable to use. 


\section{CHALLENGES}

The increasing usage of technology has now had an impact on the efficacy of learning that leads to fluency in language presentation. Language is used in all disciplines studied, including foreign languages such as French. Furthermore, the examination of the advantages of using technology includes a look at how technology is used in certain language areas. As Chun, Kern, \& Smith (2016) stated, new technological capacities in language use have been discovered to be capable of not only enhancing the possibilities of human expression, but also providing a mechanism for knowledge to be recorded and collected with technology in learning. As a result, the globe is now investigating the significance of foreign language acquisition to be used and implemented during studying.

However, due to a shortage of reference materials for learning French that have been translated into Malay, learning becomes challenging and can jeopardize students' interests. Because the subject is only taught in a few schools and colleges, learning resources are scarce (Ariffin \& Dyson, 2015). Furthermore, the cost of references is substantial, which disadvantages less privileged students. Furthermore, the majority of language learning software is translated into English, the world's lingua franca. It has been difficult to discover any language learning software utilising the Malay language, particularly for Malaysian students, due to a dearth of mobile learning software for language learning translated in Malay (Ariffin, 2016). As a result, learning other languages on the given platform must be difficult for pupils with limited English competence. Previous studies, for instance, Sung, Ahmad, Mansor, Rashid, and Abdullah (2020), have stated that to teach non-native speakers, foreign language learning is difficult since it is acquired in the form of a new language that is not normally spoken. Furthermore, highly developed software does not adhere to the correct technique outlined in the school or university curriculum. The contents offered are mostly generic, necessitating a thorough search to locate the desired topic. The present websites, for the most part, do not adhere to the syllabus offered to UKM students (Yusof et al., 2011). As a result, while there are many language learning systems available on the Internet, not all of them are of the quality we seek.

The challenges will be exacerbated if the desire to study a foreign language is not suppressed in advance. For starters, the difficulties of students and teachers in locating appropriate reference resources can dampen their enthusiasm for delving into this field of foreign languages. As concluded by Asgari, Ketabi, and Amirian (2019). to facilitate learning session, self-interest improves learners' performance. As a result, while there are many language learning systems available on the Internet, not all of them are of the quality we seek. The challenges will be exacerbated if the desire to study a foreign language is not suppressed in advance. For starters, the difficulties of students and teachers in locating appropriate reference resources can dampen their enthusiasm for delving into this field of foreign languages. Finally, respondents' suggestion for the research done by Yusof et al. (2011), which is the website's content to learn a foreign language, needs to be based on the syllabus provided. 
Finally, to address the issues that arise, the quality of software development must be increased and improved. The criteria and requirements must be thoroughly examined to avoid difficulties and confusion. To be used easily and effectively in foreign language learning, existing reference materials must be found and analyzed to increase their quality. Teachers and students must also increase their ability to use technology to stay current, since the current circulation of technology in learning is expanding.

\section{PROPOSED CONCEPTUAL SOLUTION}

This study will employ qualitative analysis techniques such as conducting interviews and focused group discussions to obtain user feedback in defining the appropriate requirement and preference from students and educators. The phases of the Waterfall Model are used to construct the system. For heuristic evaluation, quantitative analysis will be performed to determine the level of satisfaction from students and educators with the mobile learning software. This study's proposed conceptual framework diagram can be found in Figure 1.

Based on the research studies, interview and the focus group discussion, researcher will identify the suitable requirements and themes for Basic French-Malay software. Thematic analysis will be used to analyse the data as a result of the debate. The information will then be recorded, transcribed, and analysed into a few short themes. The software's usability for heuristic evaluation will be investigated in order to determine the level of satisfaction of students and instructors who use the Basic French-Malay software. 


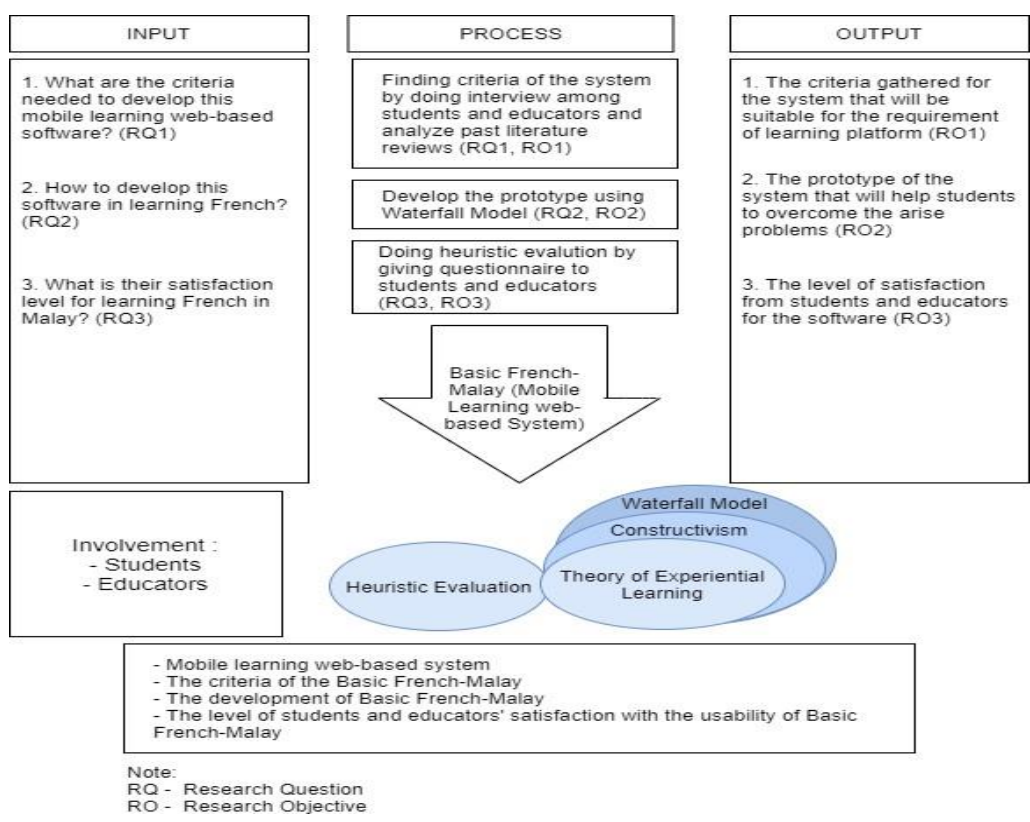

Figure 1: Proposed conceptual framework diagram of the study

\section{RECOMMENDATION}

This study used the focus group discussion technique to identify students' and teachers' perceptions in order to acquire the requirement and preference. This strategy was adopted in order to gain a better knowledge of the difficulties. According to Ariffin (2014), Malaysian students are more relaxed during the discussion to provide feedback when they are in groups. The Waterfall Model was chosen to develop the software because of several factors, including the difficulty of meeting the students or educators in person due to the pandemic and the limitations of internet usage, particularly for less privileged students, and the small group of targeted users because foreign language learning for French is still growing in Malaysia. As mentioned by Dima, Alina Maassen and Maria Alexandra (2018), Waterfall Model offers a less common presentation for consumers in system development. Following that, the questions chosen for eliciting their preferences will be of the semi-structured variety. Participants in this study were chosen on purpose rather than from a statistically representative sample of a larger group (Siti Uzairiah, 2017). Finally, once the programme has been developed, a set of heuristic usability evaluations will be applied and distributed to students and educators. The goal of heuristic assessment is to assist developers early in the development process in identifying and listing all flaws with the developed software before it is deployed (Ibrahim, Wan Ahmad \& Shafic, 2014). Furthermore, the chosen technique was chosen since it was the most 
commonly employed in comparison to others for evaluating the usability of interactive software systems (Hermawati \& Lawson, 2016; Jimenez, Lozada, \& Rosas, 2016).

\section{CONCLUSION}

Due to the difficulty of learning French, as was stated in the challenges section, this article presented a conceptual proposal framework for learning French in the Malay language using a mobile learning web-based system. Meanwhile, this article recognises French as an important foreign language, particularly for Malaysian students. Similarly, the next goal of this research is to establish the system requirements that will be a good platform for learning French in Malay. Similarly, the researcher will create a mobile learning web-based solution to assist students in overcoming difficulties in learning French. Finally, the researcher will investigate the heuristic evaluation of students and educators in mobile French learning for Malaysian students.

\section{REFERENCES}

Asgari, M., Ketabi, S., \& Amirian, Z. (2019). Interest-based language teaching: Enhancing students' interest and achievement in L2 reading. Iranian Journal of Language Teaching Research, 7(1), 61-75.

Ariffin, S. A. (2014). The contribution of mLearning to the study of local culture in the Malaysian university context [Doctoral dissertation]. Open Publications of UTS Scholars.

Ariffin, S. A., \& Dyson, L. E. (2015, August). Culturally appropriate design of mobile learning applications in the Malaysian context. In International Conference on Cross-Cultural Design (pp. 3-14). Springer, Cham.

Ariffin, S. A. (2016). Academics' perspectives on the challenges and opportunities for student-generated mobile content in Malaysia. International Journal of Mobile and Blended Learning (IJMBL), 8(3), 49-64. https://doi.org/10.4018/IJMBL.2016070104

Ariffin, S. A \& Ali, A. (2020). Students and teachers perceptions towards student-generated activities in robotics technology mobile learning: a conceptual study. In C.Y. Wong, S.R.M. Shukri, M.C. Lam, A., Ab Aziz, M.H.L. Abdullah, \& W.F.W. Ahmad (Eds.), Proceeding of $2^{\text {nd }}$ National Symposium on Human-Computer Interaction 2020 (pp. 56-60).

Azneal, I. (2018). Maszlee: Ministry looking at getting M'sians to master third language. Malaysiakini, https://www.malaysiakini.com/news/456948.

Chun, D., Kern, R., \& Smith, B. (2016). Technology in language use, language teaching, and language learning. The Modern Language Journal, 100(S1), 64-80. https://doi.org/10.1111/modl.12302

Dima, A. M., \& Maassen, M. A. (2018). From Waterfall to Agile software: Development models in the IT sector, 2006 to 2018. Impacts on company management. Journal of International Studies, 11(2), 315-326.

Gabarre, C., Gabarre, S., Din, R., Mohd Shah, P., \& Abdul Karim, A. (2014). iPads in the foreign language classroom: A learner's perspective. 3L: The Southeast Asian Journal of English Language Studies, 20(01), 115-128. https://doi.org/10.17576/31-2014-2001-09

Hermawati, S., \& Lawson, G. (2016). Establishing usability heuristics for heuristics evaluation in a specific domain: Is there a consensus? Applied Ergonomics, 56, 34-51. https://doi.org/10.1016/j.apergo.2015.11.016

Karabulut, A., Levelle, K., Li, J., \& Suvorov, R. (2012). Technology for French learning: A mismatch between expectations and reality. Calico Journal, 29(2), 341-366. https://doi.org/10.11139/cj.29.2.341-366.

Parkinson, M.M., \& Dinsmore, D. (2019). Understanding the developmental trajectory of second language acquisition and foreign language teaching and learning using the Model of Domain Learning. System, 86, 102-125. https://doi.org/10.1016/j.system.2019.102125

Siti Uzairiah, M. (2017). Kajian Kualitatif dan Analisis Temubual. Kuala Lumpur: Aras Publisher.

Sung, C. M., Ahmad, M., Mansor, N. R., Rashid, R. A., \& Abdullah, N. A. C. (2020, April). The Effectiveness of Mobile Application in Learning Malay Foreign Language. In Journal of Physics: Conference Series (Vol. 1529, No. 4, p. 042064). IOP Publishing. https://doi.org/10.1088/17426596/1529/4/042064

Ward, D. (Ed.). (2017). Why French? https://www.languagemagazine.com/2017/02/09/Why-French/. 
Wood, E. M. (2019). How Many People Speak French, And Where Is It Spoken? Babbel Magazine. https://www.babbel.com/en/magazine/how-many-people-speak-french-and-where-is-french-spoken.

Yusof, N. M., Aladdin, A., Lateh, N. H., Ramli, S., Yoan, R. S., \& Yusof, M. S. (2011). The translation of foreign language teaching and learning materials for Universiti Kebangsaan Malaysia website: Preliminary problems and challenges. Procedia-Social and Behavioral Sciences, 18, 522-526. https://doi.org/10.1016/j.sbspro.2011.05.076 